\section{EEC taps a megawatt of Italian sunshine}

THE EEC Commission and a consortium of European companies signed a construction contract in Brussels last week for a $£ 3$ million electricity generating plant operated by the sun. The plant will probably be built in the south of Italy, and should be producing a megawatt of electricity by 1981enough power for between 100 and 200 households.

Two hundred and fifty mirrors, covering a hectare of ground, will be used to reflect and concentrate the sun's heat on to a boiler, on top of a 50 -metre-high tower, to produce steam to drive conventional turbines. The heat receiver will be about four metres square. Each square metre of mirror will generate $1 \mathrm{~kW}$. The plant will have a thermal power of about $5 \mathrm{MW}$ indicating a thermal efficiency of $20 \%$. It will operate with steam at $510^{\circ} \mathrm{C}$ and
64 atmospheres. The mirrors will be computer controlled to follow the sun and the whole structure will be solid enough to withstand winds of up to $130 \mathrm{~km} \mathrm{~h}^{-1}$.

This will not be the first such solar electricity generating plant. France, which is taking part in the project, already has its own $2 \mathrm{MW}$ plant near Marseilles and Macdonnel Douglas in the USA is planning to build a $10 \mathrm{MW}$ plant in California at an estimated cost of $\$ 31$ million. But because of spending cuts that is likely to be delayed.

All these plants, however, will be expensive, experimental projects, operating on an uneconomically small scale. The maximum possible output for a solar plant is thought to be about $100 \mathrm{MW}$. Beyond that it becomes physically impossible to get more mirrors close enough to the boilers to have any effect. Major modern electricity generating stations can produce 1,000 MW, and Mr Albert Strub, head of the EEC Commission's non-nuclear energy department, estimates that "if $5 \%$ of Europe's energy comes from the sun by the year 2000 , we will be doing well",

The aim of the Italian plant is to teach the companies concerned the technical problems involved. The firms concerned are: the Italian national electrictiy company, ENEL; Ansaldo of Italy; Cethel (grouping the French companies Renault, St Gobain and Heurtey); and Messerschmitt-BolkowBlohm of West Germany. General Technology Systems of London will advise the Commission on the management of the project. Half the cost will be met from the Commission's research budget, the remainder coming from the participating countries.

Brian Donaghy
THE Royal Society of Tropical Medicine and Hygiene is holding a symposium this year, from 23 to 25 November, to celebrate the first centenary of medical entomology. It is just one hundred years since Patrick Manson showed that Culex fatigans, the common house mosquito of the tropics, was the intermediate host of a nematode worm which caused the disease filariasis in man. That was the first time an insect had been so involved, and although other scientists were engaged in parallel investigations, and there have been unpleasant confrontations between those supporting other claimants to priority, I have no doubt that Manson fully deserves this accolade.

The novelty of his discovery is manifest when we examine the records of his time. The more traditional members of the medical profession called him a lunatic, and intended to ridicule him when they gave him the nickname 'Mosquito Manson'. However, he inspired a few of his colleagues, particularly Ronald Ross. To the general public Ross, the discoverer of the transmission of malaria by the mosquito, was the more popular figure, but Ross himself always acknowledged his debt to Manson.

I do not think that it is any exaggeration to say that Manson's work has had a more profound effect on the human race than any other discovery which can be attributed to an identifiable individual. We cannot name the benefactors who discovered the wheel, the use of fire and the possibility of growing arable crops: their contributions may have been more revolutionary to man's way of life, but the results are of the same order of magnitude. But for the work of Manson and those he inspired, the populations of many tropical countries might today be less than half their present level.

\section{Mosquito Manson}

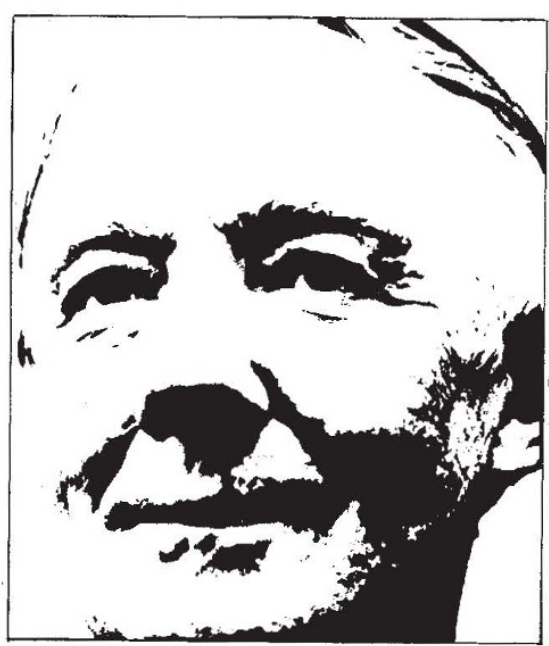

\section{KENNETH MELLANBY}

A hundred years ago the majority of the world's population lived in areas where diseases which we now know to be transmitted by insects (and in no other way) dominated the lives, and the deaths, of the inhabitants, yet no one had the faintest idea how the diseases might be controlled. Even today malaria, typhus, sleeping sickness, filariasis, dengue and many more diseases are still important, claiming many victims and affecting all types of development, but we know how they could be reduced or even eradicated. Though patchy, some degree of control has been widely implemented. The resulting rise in population may not be an unmixed blessing in a world of shrinking resources, but to many individuals, particularly in tropical countries, the improvement has been dramatic.

Although a hundred years ago no one appeared to believe that insects could carry diseases, it is tempting to search for earlier suggestions of such a mechanism. It is true that authoritative books on the English fens produced in the nineteenth century which devote much space to "the ague", which was generally malaria, give no inkling of any idea other than that the disease was caused by the "bad air" from the marshes. They discuss the importance or otherwise of water pollution by organic matter, which can now be interpreted as affecting the survival of mosquito larvae, but there is no mention of mosquito bites as a danger to health. However, I recently found a contemporary account giving an inventory of the contents of the Cistercian Abbey at Sawtry, only a couple of miles from where I write in Huntingdonshire, at the time of the dissolution of the monasteries in the sixteenth century. The Abbot's chamber had a feather bed and white curtains, but the guest room, reserved for important visitors, was hung with tapestry and a bedstead with "nets for knats". This may have been to protect the guests from infection with malaria, but I fear that it was just for his comfort and to keep out the insects which can still be troublesome on warm summer nights in fenland. But it may have kept him healthy all the same. 